\title{
'Residual bodies' in sarcoid and sarcoid-like granulomas
}

\author{
W. JONES WILLIAMS AND D. WILLIAMS
}

From the Welsh National School of Medicine, Cardiff

SYNOPSIS A morphological and histochemical study was made of epithelioid cell granulomas (a) classical sarcoid type, namely, sarcoidosis, Kveim tests, tuberculosis, farmer's lung, and Crohn'su syndrome; $(b)$ sarcoid-like granulomas, often distinguishable from $(a)$ by the presence of extracellular mucin or bile, namely, ulcerative colitis, diverticulitis, cholecystitis, cholangitis, carcinomæij of the rectum and lymph nodes, draining tumours. All these granulomas showed similar, numerous $P$ cytoplasmic granules in epithelioid and giant cells with the properties of residual bodies, i.e., encF products of activated lysosomes. The presence of residual bodies demonstrates the following features the morphological similarity of the granulomas studied, and the phagocytic nature of the affected cells. It suggests a common mechanism of granuloma formation but does not identify any particular exogenous cause. The findings suggest that Boeck's sarcoidosis may be caused by unidentified? exogenous agents.

A morphological and histochemical study of sarcoid and sarcoid-like granulomas demonstrates the presence of cytoplasmic granules in epithelioid and giant cells. They are thought to be 'residual bodies', i.e., end products of activated lysosomes(Weissmann, 1965). The significance of these findings is discussed with particular reference to the aetiology of sarcoidosis.

The granulomas in tuberculosis, chronic beryllium disease (Jones Williams, 1958), Crohn's syndrome (Jones Williams, 1964), the Kveim test (Kveim, 1941), and farmer's lung (Dickie and Rankin, 1958), are often identical with those of sarcoidosis and may be called 'classical sarcoid granulomas' (Fig. 1). The rare 'sarcoid-like granuloma' (Fig. 2), as in cholecystitis, cholangitis, ulcerative colitis, diverticulitis, and rectal carcinoma, are distinguished from the above by the frequent presence of extracellular mucins and/or bile (Jones Williams, 1967). Sarcoid-like granulomas may also be seen in lymph nodes draining tumours (Gregorie, Othersen, and Moore, 1962).

MATERIAL AND METHODS

Table I shows the diseases studied, the number of cases, and the type of granuloma examined. The site and distribution of the material is as follows: sarcoidosis, 15 lungs, 6 lymph nodes; Kveim granulomas, 6, all skin,

Received for publication 28 February 1967.
TABLE I

TYPES OF GRANULOMA DISEASES, AND NUMBER OF CASES

\begin{tabular}{|c|c|c|c|}
\hline & & & \\
\hline $\begin{array}{l}\text { Classical Sarcoid } \\
\text { Condition }\end{array}$ & $\begin{array}{l}\text { No. of } \\
\text { Cases }\end{array}$ & $\begin{array}{l}\text { Sarcoid-like } \\
\text { Condition }\end{array}$ & \\
\hline $\begin{array}{l}\text { Sarcoid } \\
\text { Kveim test } \\
\text { Tuberculosis } \\
\text { Chronic beryllium } \\
\text { disease }\end{array}$ & $\begin{array}{r}21 \\
6 \\
12 \\
7\end{array}$ & $\begin{array}{l}\text { Ulcerative colitis } \\
\text { Diverticulitis } \\
\text { Cholecystitis } \\
\text { Cholangitis }\end{array}$ & $\begin{array}{l}2 \\
2 \\
5 \\
1\end{array}$ \\
\hline $\begin{array}{l}\text { Farmer's lung } \\
\text { Crohn's syndrome }\end{array}$ & $\begin{array}{r}3 \\
14\end{array}$ & $\begin{array}{l}\text { Carcinoma rectum } \\
\text { Lymph nodes } \\
\text { draining tumours }\end{array}$ & 2 \\
\hline
\end{tabular}

tuberculosis, 5 skin, 4 lung, 2 ileum, and 1 brain; chronif beryllium disease, 5 lungs and 2 skin; farmer's lung, $3 \stackrel{\text { : }}{\%}$ Crohn's syndrome, 5 ileum, 3 colon, 3 skin fistulae, and 3 lymph nodes; ulcerative colitis, 2; diverticulitis, 20 cholecystitis, 5 ; cholangitis, 1 ; carcinoma of rectum $2 \mathrm{O}$ lymph nodes draining carcinoma cervix, 1 .

The material consisted mainly of formalin-fixed tissues paraffin blocks, and sections. In one beryllium skin granuloma and two tuberculous lymph nodes fres? material was also available. Sections were stained rou霖 tinely with haematoxylin and eosin. They were examined under direct, polarized, phase contrast, and some under ultra-violet light.

The following histochemical tests were performeक periodic acid-Schiff (P.A.S.), to show muco- and glyco $\stackrel{\square}{\mathbb{D}}$ proteins, controlled with diastase; Alcian blue, to demon ${ }_{\sigma}$ strate acid mucopolysaccharides, controlled with hyalase. Sudan black B and luxol fast blue, to demonstrate phosê 


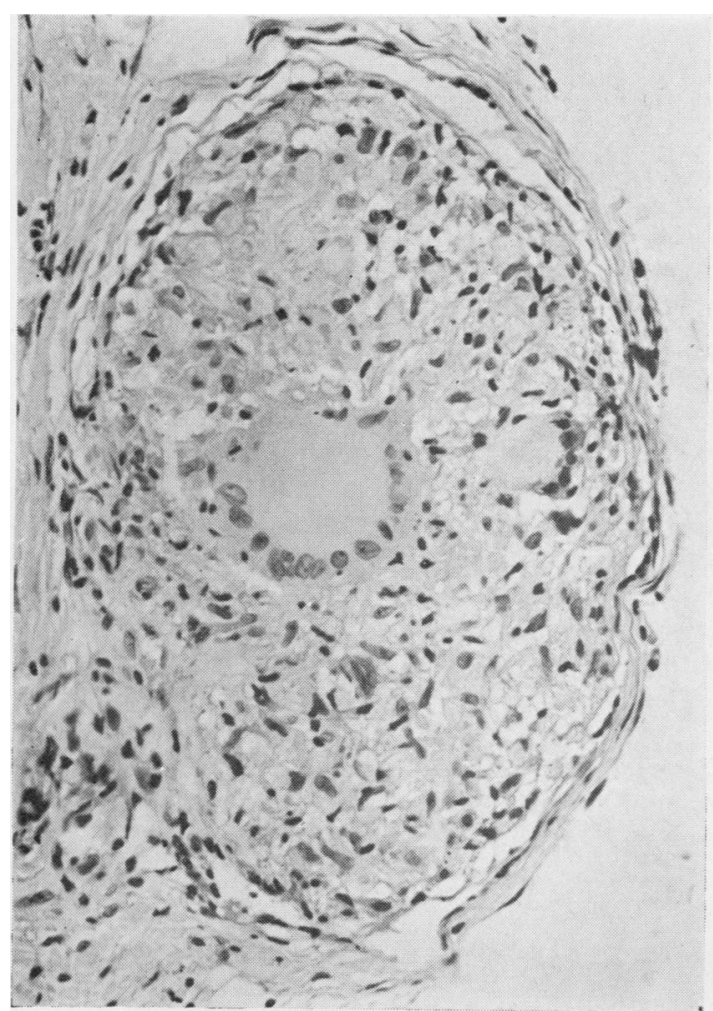

FIG. 1. Classical sarcoid granuloma (Boeck's sarcoid). Haematoxylin and eosin $\times 350$.

pholipids and lipoprotein, controlled by chloroform/ methanol extraction; Feulgen and methyl green pyronine to show desoxy- and ribonucleic acids (D.N.A. and R.N.A.) respectively, controlled by D.N.ase and R.N.ase extraction; Perls's stain for iron; Von Kossa and alizarin red for calcium. In addition Barka and Anderson's coupling Azo dye and Holt's modification of Gomori's method to demonstrate acid phosphatases were performed on cases with available fresh tissue. Long ZiehlNeelson staining was also performed on a few cases to show acid fastness and Sudan stains for neutral lipids.

\section{RESULTS}

In haematoxylin-and-eosin-stained sections of all the granulomas studied, both epithelioid and giant cell show very numerous cytoplasmic granules about $1 \mu$ in diameter. The main properties of the granules are summarized in Table II. In giant cells they tend to be aggregated and account for the denser eosinophilic centres seen at low magnification (Fig. 1). None are birefringent. They are easily visible with phase contrast.

Though the majority of the granules are colourless, some are occasionally yellowish brown and

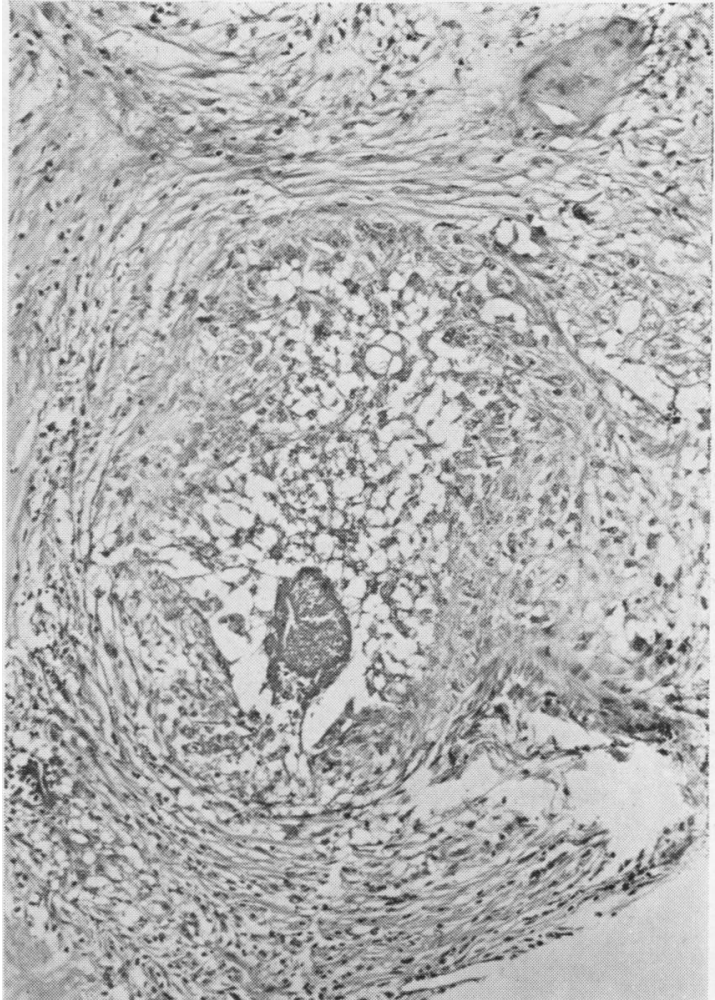

FIG. 2. Sarcoid-like granuloma in cholecystitis. Haematoxylin and eosin $\times 100$.

TABLE II

\section{PROPERTIES OF INTRACYTOPLASMIC GRANULES}

\begin{tabular}{|c|c|}
\hline Position & Epithelioid and giant cells \\
\hline Morphology & Granular, $1 \mu$ diameter \\
\hline Physical & $\begin{array}{l}\text { Colourless or yellowish brown } \\
\text { Not birefringent } \\
\text { Faintly autofluorescent in ultra-violet light }\end{array}$ \\
\hline Histochemical & $\left.\begin{array}{l}\text { Lipo- and mucoprotein } \\
\text { (S.B.B., L.F.B., P.A.S., A.B.) } \\
\text { Acid phosphatase } \\
\text { (Azo dye, Gomori) }\end{array}\right\} \quad$ Positive \\
\hline
\end{tabular}

might be considered to be lipofuscin. Table III compares the results obtained for our pigmented granules with the properties for lipofuscin as recorded in the literature (Pearse, 1960; Lillie, 1965). They are distinct from lipofuscin because they are paler, show bluish white autofluorescence, are not sudanophilic, not basophilic, $60 \%$ stain with alcian blue and only $20 \%$ are acid fast.

The majority of the granules stain with Sudan black B (Fig. 3.) and Luxol fast blue, demonstrating the presence of lipoproteins and with P.A.S. and Alcian blue showing the presence of mucoproteins and acidic polysaccharides. In some $50 \%$ the granules stain with methyl green pyronin demonstrating the 
TABLE III

A COMPARISON OF PIGMENTED RESIDUAL BODIES AND LIPOFUSCIN

\begin{tabular}{|c|c|c|}
\hline Test & Pigmented Residual Bodies & Lipofuscin \\
\hline & $\begin{array}{l}\text { Pale yellow or yellowish } \\
\text { brown }\end{array}$ & Yellow-brown \\
\hline Autofluorescence & Bluish white & $\begin{array}{l}\text { Yellow-reddish } \\
\text { brown }\end{array}$ \\
\hline Sudanophilia & - & + \\
\hline Basophilia & - & + \\
\hline Alcian blue & $+(60 \%)$ & - \\
\hline Acid fast & $-(80 \%)$ & + \\
\hline
\end{tabular}

presence of R.N.A. The majority, in the fresh tissue examined, stain with Azo dye (Fig. 4) and Gomori stain for acid phosphatase. They do not stain for D.N.A., iron, calcium, or neutral lipid.

It is noted that the granules in all the granulomas studied are histochemically identical, irrespective of the type of granuloma, site of the lesion, known or unknown cause, and duration of the lesion.

These properties show the granules to be of the lysosomal origin. They are distinguishable from Schaumann bodies (Jones Williams, 1960). Their properties also distinguish them from bacteria, viruses, or fungi.

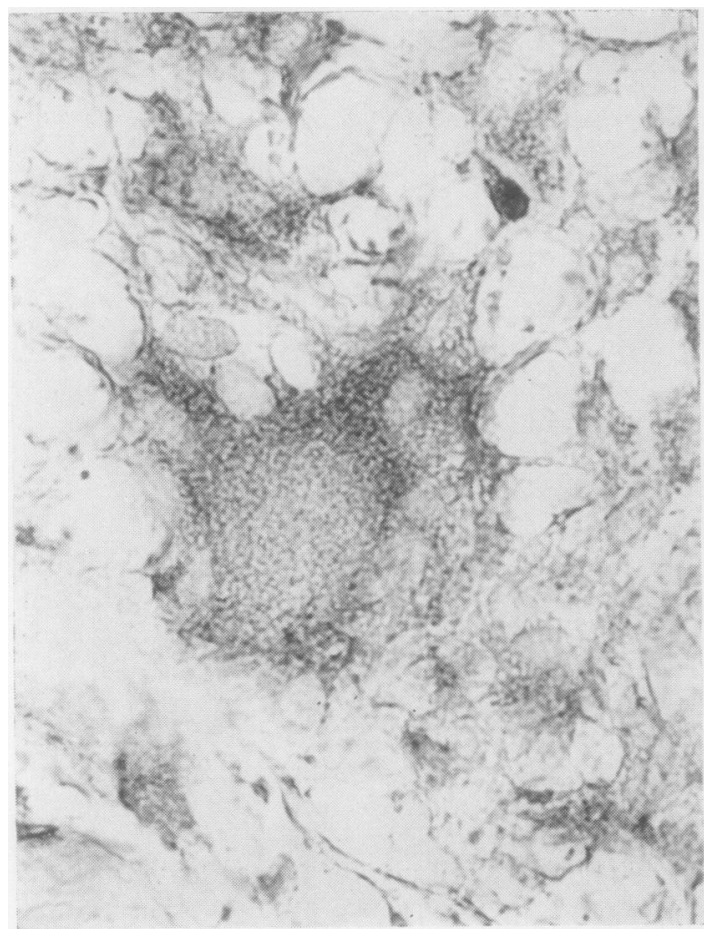

FIG. 3.

FIG. 3. Sarcoid granuloma in lymph node. Residual bodies in a giant cell. Sudan black $B \times 886$.

FIG. 4. Beryllium granuloma of skin. Azo dye $\times 50$.
DISCUSSION

Lysosomes participating in a process of digestion $\underset{\vec{D}}{\vec{D}}$ are often characterized by the presence of undigested inert residues, usually lipid, and are then termed residual bodies, (Weissmann, 1965; de Duve and Wattiaux, 1966). Our results show that the cytoplasmic granules described by virtue of their acid phosphatase, lipid, mucopolysaccharide, and R.N.A क content are identified as activated lysosomes or $\vec{O}$ residual bodies. The variation in our histochemical $\vec{\overrightarrow{ }}$ staining reflects that, as expected, residual bodies $\stackrel{\omega}{\omega}$ may be derived from different sources.

Lipofuscin is described as a type of pigmented indigestible material sometimes forming residual $O$ bodies (Goldfischer, Villaverde, and Forschirm, 1966). However, our pigmented residual bodies differ in staining properties and appear to be 0 distinct from lipofuscin.

The presence of residual bodies demonstrates $\vec{c}$ that the cells are or have been actively phagocytic. There are two alternative modes of formation of $\vec{\varphi}$ residual bodies: either they arise from autodigestion of cells by the process of autophagocytosis, or they

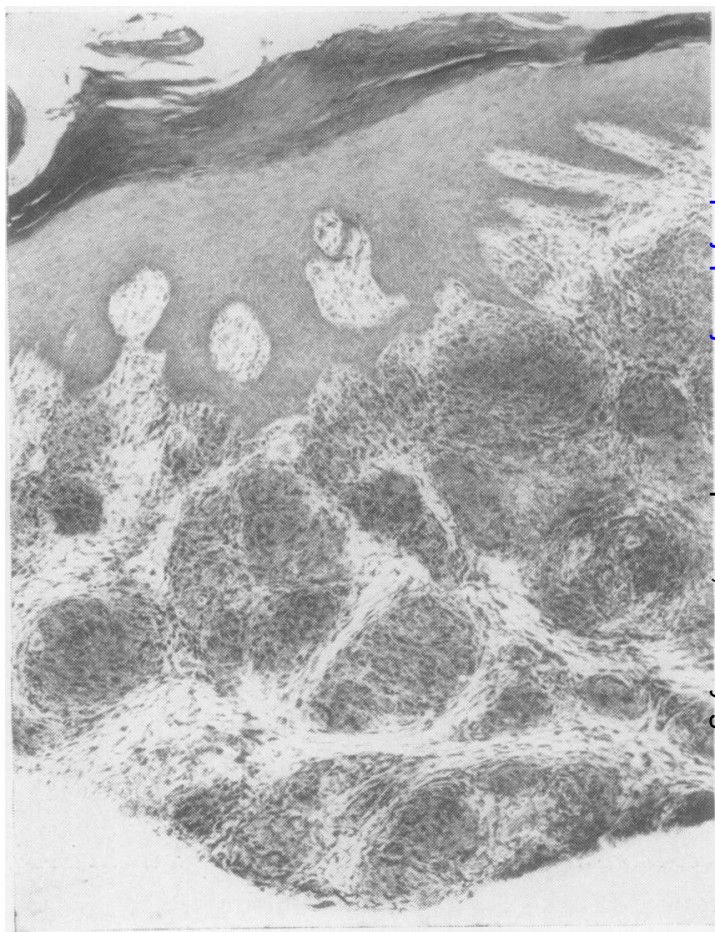

FIG. 4. 
are undigested remnants of phagocytosed extracellular material, heterophagocytosis (de Duve and Wattiaux, 1966).

First, to consider whether they are of autophagic origin. They would then be the result of the action of one of many cell-damaging agents ranging from toxins to anoxia (de Duve and Wattiaux, 1966). The presence of ribonucleoprotein in many of the granules might suggest an origin from endoplasmic reticulin. If so, their large numbers might suggest a dying cell but the nuclear and cytoplasmic features are well preserved. This evidence is therefore inconclusive.

Secondly, to consider a heterophagocytosis origin. There have been many attempts to demonstrate microorganisms in sarcoid and Crohn's granulomas, particularly tubercle bacilli, but without success. It is very important in such searches that the presence of residual bodies is recognized. Acid phosphatase is the most valuable differentiating test, as it is the characteristic marker for lysosomes and therefore for residual bodies. However, residual bodies may be end products of microorganisms and as such could have come from bacteria, fungi, or viruses. They are not diagnostic of any one particular exogenous agent. Their large number in the cells in the absence of evidence of cell death suggests that they are of exogenous origin. Their positive staining for lipoproteins and the occasional Ziehl-Nielson-positive pigmented bodies may lead to confusion with tubercle bacilli but acid phosphatase staining shows their true nature.

The other possible exogenous material to be considered is phospholipid. Apart from being present in some microorganisms, notably tubercle bacilli, they are widely dispersed in the tissues. Phospholipids experimentally can induce sarcoidlike granuloma (Refvem, 1954). Bile and faeces are very rich in lipoproteins and also in mucopro- teins. In the case of alimentary tract classical sarcoid and sarcoid-like granulomas, it is tempting to suggest that these substances are an initiating cause. This may be the case with sarcoid-like granulomas, as free lipo- and mucoproteins are often found but are not found in Crohn's granulomas, nor in the granulomas of sarcoidosis and chronic beryllium disease (Jones Williams, 1967).

The finding of similar bodies with identical properties in all these granulomas suggests a common mode of formation. Tuberculosis, beryllium disease, and farmer's lung are caused by known external agents. Sarcoid-like granulomas of alimentary tract may be caused by a reaction to displaced lipo- and mucoproteins. The evidence presented, therefore, suggests that the granulomas of Boeck's sarcoidosis and Crohn's syndrome may also be caused by some external agents. However, residual bodies do not identify the exact nature of the possible external agents.

We wish to thank Dr. R. M. E. Seal for access to his farmer's lung material, Mr. P. Stinchcombe for the photomicrographs, and Mrs. V. M. Gruffydd for typing the manuscript.

\section{REFERENCES}

de Duve, C., and Wattiaux, R. (1966). Ann. Rev. Physiol., 28, 435. Dickie, H. A., and Rankin, J. (1958). J. Amer. med. Ass., 167, 1069. Goldfischer, S., Villaverde, H., and Forschirm, R. (1966). J. Histochem. Cytochem., 14, 641.

Gregorie, H. B., Jr., Othersen, H. B., Jr., and Moore, M. P., Jr. (1962). Amer. J. Surg., 104, 577.

Kveim, A. (1941). Nord. Med., 9, 169.

Lillie, R. D. (1965). Histopathologic Technique and Practical Histochemistry, p. 410. McGraw-Hill, New York.

Pearse, A. G. E. (1960). Histochemistry, 2nd ed., p. 661. Churchill, London.

Refvem, O. (1954). Acta med. scand., suppl. 294.

Weissmann, G. (1965). New Engl. J. Med., 273, 1084.

Williams, W. J. (1958). Brit. J. industr. Med., 15, 84.

(1960). J. Path. Bact., 79, 193.

(1964). Gut, 5, 510.

(1967). Rep. IV int. Confr. Sarcoidosis, Paris. In the press. Masson, Paris. 